\title{
Autosomal Dominant Polycystic Kidney Disease: Recent Advances in Pathogenesis and Treatment
}

\author{
Ming-Yang Chang ${ }^{\mathrm{a}, \mathrm{b}} \quad$ Albert C.M. Ong ${ }^{\mathrm{a}}$

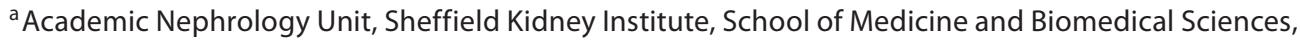

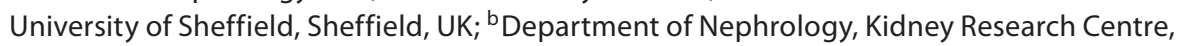 \\ Chang Gung Memorial Hospital, Chang Gung University, Taoyuan, Taiwan
}

\section{Key Words}

Autosomal dominant polycystic kidney disease $\cdot$ Epithelial cyst - Renal parenchyma - Arterial aneurysms, intracranial

\begin{abstract}
Autosomal dominant polycystic kidney disease (ADPKD) is a common genetic disorder affecting 1 in 1,000 people in the general population and accounts for up to $10 \%$ of all patients on renal replacement therapy. Numerous fluid-filled epithelial cysts arise from different nephron segments as spherical dilatations or small out-pouchings, enlarge progressively and eventually become disconnected from the rest of the renal tubule. The development of cysts is accompanied by destruction of the renal parenchyma, interstitial fibrosis, cellular infiltration and loss of functional nephrons. ADPKD is not only a kidney disease but also a systemic disorder associated with intracranial arterial aneurysms, cardiac valvular defects, colonic diverticulosis and cyst formation in other organs such as the liver, spleen and pancreas. The identification of PKD1 and PKD2 together with the drive to elucidate the functions of their encoded proteins, polycystin-1 (PC1) and polycystin-2 (PC2), has led to an explosion of clinical and scientific interest in this common disorder. The aim of this review is to highlight recent advances in our understanding of ADPKD pathogenesis which are leading to exciting new treatment strategies.
\end{abstract}

Copyright $\odot 2007$ S. Karger AG, Basel (c) 2007 S. Karger AG, Basel

$1660-2137 / 08 / 1081-0001 \$ 24.50 / 0$

Fax +41613061234

E-Mail karger@karger.ch

www.karger.com
Accessible online at:

www.karger.com/nep

\section{Molecular Genetics of ADPKD}

Autosomal dominant polycystic kidney disease (ADPKD) can arise from mutations in either PKD1 (85\%) or PKD2 (15\%) with clinically indistinguishable manifestations. However, PKD2 is usually of later onset since the mean age at end-stage renal disease (ESRD) occurs 16 years later than PKD1 (69.1 vs. 53.0 years) [1]. So far, no apparent clustering or 'hot spot' of mutations has been identified in either gene. Most mutations are predicted to truncate the protein or lead to its degradation. However, production of a partially functional mutant protein has not been excluded. The search for possible genotype/phenotype correlations has yielded mixed results. Mutations in the $5^{\prime}$ half of $P K D 1$ (relative to the median nucleotide) have been shown to be associated with slightly earlier ESRD compared to mutations in the $3^{\prime}$ half of the gene and are also more strongly associated with aneurysm rupture [2,3]. A clear genotype/phenotype correlation for PKD2 has not been found [4]. The considerable intrafamilial phenotypic variability, even in patients with identical mutations, reflects the strong influence of additional genetic modifiers and/or environmental factors on disease progression in ADPKD $[5,6]$.

Modifier genes could regulate the function of polycystin-1 (PC1) and polycystin-2 (PC2) by affecting polycystin-mediated signal transduction pathways, the rate of somatic mutations, cyst fluid accumulation or other clin-

Dr. Albert C.M. Ong, Kidney Genetics Group

Academic Nephrology Unit, The Henry Wellcome Laboratories for Medical Research

School of Medicine and Biomedical Sciences, University of Sheffield

Beech Hill Road, Sheffield S10 2RX (UK)

Tel. +44 114271 3402, Fax +44 114271 1711, E-Mail a.ong@sheffield.ac.uk 
ical factors associated with cyst initiation or disease progression [7]. In human ADPKD, these modifier genes are not well defined although several candidate loci have been investigated in small populations [8]. Confirmatory studies are required to clarify the modifying effects of these genes in larger well-defined ADPKD populations.

\section{Mutational Mechanisms Underlying Cystogenesis}

The mutational mechanism underlying cyst initiation in ADPKD remains controversial. Strong evidence for a two-hit mechanism has been presented which could help explain the focal nature of cyst development and the variability of the cystic phenotype $[9,10]$. Nevertheless, there is accumulating data that haploinsufficiency itself may be sufficient to elicit a switch to a cystic phenotype. The strongest experimental evidence for this model has come from the generation of $\mathrm{Pkd} 1$ hypomorphs where a reduction, but not absence, of $P k d 1$ was sufficient to initiate renal and, in one study, extrarenal (vascular) features of ADPKD [11, 12]. Overexpression of PKD1 itself leads to cyst formation, implying that gene dosage is important $[13,14]$. Of interest, Pkd1 heterozygous mice develop inappropriate anti-diuresis, and increased proliferative activity has been observed in the non-cystic tubules of Pkd2 heterozygous mice $[15,16]$. Both Pkd1 heterozygous collecting ducts and Pkd2 heterozygous vascular smooth muscle cells have lower intracellular $\mathrm{Ca}^{2+}$ levels $[15,17]$. These findings appear to precede loss of a flow-sensitive (cilia) $\mathrm{Ca}^{2+}$ response observed in PC1 null cells as the latter is retained in PKD1 or Pkd1 heterozygous tubular cells [18]. Thus, current evidence indicates that loss of a single allele of either $P K D 1$ or $P K D 2$ is sufficient to initiate phenotypic changes in tubular cells, activating a pathway which ultimately leads to cyst formation.

\section{Functions of the Polycystin Proteins}

\section{Polycystin-1 (PC1)}

PC1 is a 4,302-amino acid type I membrane glycoprotein containing a long $\mathrm{N}$-terminal extracellular domain of over 3,000 amino acids, 11 transmembrane domains and a short cytoplasmic C-terminus (198 amino acids) [19]. PC1 interacts with PC2 via its C-terminus to form a heterodimeric complex. This primary interaction is critical for the functional regulation of both proteins [20].

A number of potential structural domains in the $\mathrm{N}$ terminus may directly or indirectly (through E-cadherin or $\beta_{1}$-integrin) mediate cell-cell or cell-matrix interactions [7]. A direct role of $\mathrm{PC1}$ in mediating cell-cell adhesion via homophilic interactions of the PKD domains has been demonstrated [21]. Heterophilic interactions of other domains (LRR, C-lectin) with purified extracellular matrix proteins have also been described. Of interest, the entire $\mathrm{N}$-terminal ectodomain has the biomechanical properties of a mechanosensor [22]. Potentially it could sensor laminar flow or the force of coupling between cells or cell-matrix attachments during tubulogenesis. These force-triggered events could in turn activate a PC2-dependent $\mathrm{Ca}^{2+}$ signal and/or PC1-dependent signals. In addition to $\mathrm{Ca}^{2+}$, the latter could include activation of monomeric GTPase proteins (Ras, Rho), heterotrimeric G proteins (Gi and Go), JAK/STAT, phosphatidylinositol 3-kinase (PI3-K)/Akt/mammalian target of rapamycin (mTOR) and activator protein 1 (AP-1)/mitogen-activated protein kinases (MAPK) pathways [7]. Finally, PC1 may undergo a stimulus-triggered proteolytic cleavage event to release its C-terminal tail - a process termed 'regulated intramembrane proteolysis' or RIP [23]. This fragment could translocate to the nucleus to directly initiate gene transcription.

\section{Polycystin-2 (PC2)}

PC2 is a 968 -amino acid type II membrane glycoprotein with six transmembrane domains and intracellular $\mathrm{N}$ - and C-termini. PC2 (or TRPP2) has significant homology to the transient receptor potential (TRP) family of store-operated calcium channels and is likely to function similarly as a non-selective calcium channel [24]. Unlike Pkd1 mice, Pkd2 knockout mice were unexpectedly found to have a defect in left-right patterning of the body axis: PC2 (but not PC1) is expressed by monocilia at the mouse embryonic node and may mediate the asymmetric $\mathrm{Ca}^{2+}$ signal proximal to the establishment of leftright asymmetry [25]. Similarly, PC2 (together with PC1) has been shown to mediate flow-induced $\mathrm{Ca}^{2+}$ signals originating from primary cilia of kidney epithelial cells [26].

The subcellular location of PC2 has been an area of controversy with immunolocalisation to the endoplasmic reticulum (ER), lateral plasma membrane and primary cilia. PC2 does not contain a classical ER retention signal; rather, a stretch of acidic residues containing a casein kinase 2 phosphorylation site $\left(\mathrm{Ser}^{812}\right)$ appears to mediate its retrograde trafficking between the ER, Golgi and plasma membrane compartments [27]. A second phosphorylation site for PC2 within its N-terminal domain $\left(\mathrm{Ser}^{76}\right)$ is critical for its localization in the lateral plasma p2

Nephron Physiol 2008;108:p1-p7
Chang/Ong 
membrane but not in the primary cilia [28]. A ciliary localisation signal in its $\mathrm{N}$-terminus has also been described [29]. These three distinct non-overlapping recognition motifs could determine the subcellular location of PC2 and hence its function within different compartments. Finally, there is evidence that PC2 channel activity can be modulated by its interaction with the actin (lateral membrane?) or microtubule (cilia?) cytoskeleton [30, 31].

\section{Mechanisms of Cyst Formation}

Human and experimental data suggest several potential mechanisms that could lead to cyst formation in ADPKD: (1) increased cell proliferation and apoptosis; (2) enhanced fluid secretion; (3) abnormal cell-matrix interactions; (4) alterations in cell polarity, and (5) abnormal ciliary structure or function.

\section{Cell Proliferation and Apoptosis}

A primary increase in tubular proliferative activity, e.g. through the transgenic expression of oncogenes or grow th factors, can lead to cyst formation [32]. PKD1 cystic epithelial cells are more sensitive to the mitogenic effect of growth factors and cAMP in vitro - these effects are dependent on Ras and Raf activity [33]. ADPKD cystic cells also have lower intracellular $\mathrm{Ca}^{2+}$ concentrations and this appears to correlate with their responsiveness to cAMP via a B-Raf/ERK pathway [34]. A potential approach to inhibit cAMP-dependent cell proliferation could be by restoring intracellular $\mathrm{Ca}^{2+}$ regulation in these cells - this may be the basis of action of triptolide, a recently described natural compound, on cyst formation in Pkd1 null mice [35].

A primary defect in apoptotic regulation (e.g. bcl-2 null mice) can result in a cystic phenotype [36]. In human ADPKD tissue, high levels of c-myc expression have been found [37]. Moreover, kidney-specific overexpression of c-myc (SBM mice) leads to a cystic phenotype and an increase in both proliferation and apoptosis [38]. Conversely, transgenic expression of human PC1 in MDCK cells can induce growth inhibition and resistance to apoptosis suggesting that, like c-myc, PC1 could exert independent effects on both cellular processes [39].

\section{Fluid Secretion}

In patients with ADPKD, the tubular epithelium appears to switch from an absorptive to a secretory phenotype. Tubular secretion is primarily mediated by transepithelial $\mathrm{Cl}^{-}$secretion with passive $\mathrm{Na}^{+}$and water move- ment [40]. Chloride transport could be mediated by several channels including the cystic fibrosis transmembrane conductance regulator and $\mathrm{Ca}^{2+}$-sensitive $\mathrm{Cl}^{-}$channels [41, 42]. Intracellular cAMP and extracellular ATP may be involved in regulating this process $[43,44]$. Recently, forskolin, a potent stimulator of adenylate cyclase, has been isolated from human ADPKD cyst fluid samples [45].

\section{Cell-Matrix Interactions}

A primary defect in laminin synthesis has recently been shown to cause PKD in a study describing a hypomorphic allele of laminin $\alpha_{5}$ [46]. ADPKD cyst epithelia sit on an expanded basement membrane and abnormal increases in basement membrane components (laminin, fibronectin, type IV collagen, and heparan sulphate proteoglycan), and interstitial type I collagen have been reported. These changes in basement membrane composition could contribute to cyst initiation or expansion. PC1-deficient cystic cells have been shown to adhere more strongly to type I collagen by a $\beta_{1}$-integrin-dependent mechanism and may mediate resistance to anoikis $[47,48]$.

\section{Cell Polarity}

Alterations in apicobasal or planar cell polarity have been described in several cystic cell models, although not always consistently. Mislocation of E-cadherin (to the apical surface) could impair the subsequent targeting of protein assemblies crucial for basolateral trafficking and could account for the observation of mislocalised basolateral proteins (e.g. EGF receptor, $\mathrm{Na}^{+}-\mathrm{K}^{+}$-ATPase) in ADPKD cyst epithelia [49]. Alternatively, abnormalities in planar cell polarity (Wnt signalling in NPHP2/inv mice) or oriented cell division (spindle orientation in HNF- $\beta 1$ mice) during tubular lengthening could be key mechanisms underlying cyst formation in some recessive models of PKD or nephronophthisis [50, 51].

\section{Ciliary Structure and Function}

A recent major theme in the elucidation of PKD pathogenesis is the association between structural abnormalities of the primary cilia (a previously neglected organelle) and a cystic phenotype [52]. Among several seminal observations were the findings that the worm pkd1 and pkd2 orthologues are functionally important in mechanosensory neuronal cilia and that PKD mice hypomorphic for Tg737/ polaris have short kidney primary cilia [53, 54]. Many cystoproteins have since been immunolocalised to primary cilia or centrosomes (which give rise to primary cilia) and 
Table 1. Comparison of potential treatments for PKD

\begin{tabular}{|c|c|c|c|c|c|c|}
\hline Compound & Mechanism & Molecular target & PKD models & Potential side effects & $\begin{array}{l}\text { Effect on } \\
\text { liver cysts }\end{array}$ & $\begin{array}{l}\text { Reference } \\
\text { No. }\end{array}$ \\
\hline Rapamycin & Antiproliferative & mTOR & $\begin{array}{l}\text { Han:SPRD rat } \\
\text { orpk mice } \\
\text { bpk mice } \\
\text { Human }\end{array}$ & $\begin{array}{l}\text { Oral mucositis, tremor, } \\
\text { hypertension }\end{array}$ & Unknown & 65 \\
\hline $\begin{array}{l}\text { Vasopressin V2R } \\
\text { antagonist }\end{array}$ & $\begin{array}{l}\text { Inhibit fluid secretion and } \\
\text { cell proliferation }\end{array}$ & cAMP & $\begin{array}{l}\text { pcy mice } \\
\text { PCK rat } \\
\text { Pkd2 } 2^{\text {WS25/- }}\end{array}$ & Hypernatremia, thirst & No & 60 \\
\hline Somatostatin & $\begin{array}{l}\text { Inhibit fluid secretion and } \\
\text { cell proliferation }\end{array}$ & cAMP & $\begin{array}{l}\text { PCK rat } \\
\text { Human }\end{array}$ & $\begin{array}{l}\text { Diarrhoea, anorexia, } \\
\text { gallstones }\end{array}$ & Yes & 61 \\
\hline Triptolide & Antiproliferative & $\begin{array}{l}\mathrm{Ca}^{2+} \text { signalling } \\
(\mathrm{PC} 2 \text {-dependent })\end{array}$ & $\begin{array}{l}\text { Pkd1 } 1^{-/-} \text {mice } \\
\text { (from E10.5) }\end{array}$ & Male infertility & Unknown & 35 \\
\hline Roscovitine & Antiproliferative & $\begin{array}{l}\text { Cyclin-dependent } \\
\text { kinases }(\mathrm{Cdk})\end{array}$ & $\begin{array}{l}\text { cpk mice } \\
\text { jck mice }\end{array}$ & $\begin{array}{l}\text { Nausea, transient elevation } \\
\text { of creatinine, hypokalemia }\end{array}$ & Unknown & 58 \\
\hline $\begin{array}{l}\text { Tyrosine kinase } \\
\text { inhibitor }\end{array}$ & Antiproliferative & EGF receptor & $\begin{array}{l}\text { bpk mice } \\
\text { Han:SPRD rat }\end{array}$ & Diarrhoea, rashes & No & 66,67 \\
\hline Batimastat & Inhibit matrix degradation & Metalloproteinases & Han:SPRD rat & Arthralgia & Unknown & 68 \\
\hline Caspase inhibitor & Antiapoptosis & Caspases & Han:SPRD rat & Diarrhoea & Unknown & 69 \\
\hline Pioglitazone & Antiproliferative & $\begin{array}{l}\text { Peroxisome- } \\
\text { proliferator-activated } \\
\text { receptor- } \gamma(\text { PPAR- } \gamma)\end{array}$ & $\begin{array}{l}\mathrm{Pkd}^{-/-} \text {mice } \\
\text { (from E7.5) }\end{array}$ & $\begin{array}{l}\text { Hypoglycemia, weight } \\
\text { gain, fluid retention }\end{array}$ & Unknown & 70 \\
\hline
\end{tabular}

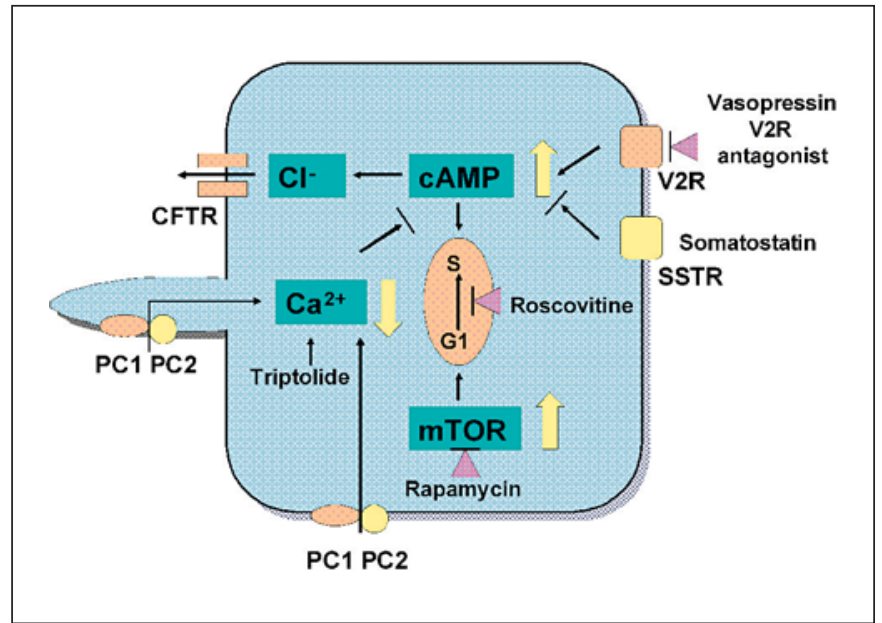

Fig. 1. Hypothetical scheme of signalling abnormalities and molecular targets in ADPKD. Major inhibitors are indicated by the pink arrowheads. The yellow arrows indicate key changes in signalling intermediates. CFTR $=$ Cystic fibrosis transmembrane conductance regulator; $\mathrm{mTOR}=$ mammalian target of rapamycin $\mathrm{PC} 1$ = polycystin $-1 ; \mathrm{PC} 2$ = polycystin $-2 ; \mathrm{V} 2 \mathrm{R}=$ vasopressin $\mathrm{V} 2$ receptor; $\mathrm{SSTR}=$ somatostatin receptor . some have been associated with structural or functional abnormalities of these organelles. Indeed, kidney-specific inactivation of Kif3A, a protein involved in the maintenance of renal ciliary structure, can itself lead to PKD [55]. In PKD1, the major ciliary abnormality does not appear to be structural, but rather functional: Pkd1 null collecting duct cells or human cyst-lining cells have defects in flowinduced ciliary $\mathrm{Ca}^{2+}$ signals $[18,26,56]$. How abnormalities in ciliary $\mathrm{Ca}^{2+}$ signals lead to the complex cystic phenotype of ADPKD cells (see above) and hence cystogenesis itself is the focus of intense investigation.

\section{Treatment Targets for ADPKD}

Figure 1 summarises some of the major advances in our present understanding of the cellular mechanisms underlying the cystogenesis in ADPKD. These in turn have led to some interesting new molecular targets as potential treatments (table 1). Overall, these approaches can be summarised into two major ones: targeting cell proliferation and lowering cAMP.

In view of the pronounced increase in tubular proliferation, several groups have attempted an anti-prolifera- 
tive strategy in experimental models. Examples of these are the use of rapamycin (to inhibit mTOR), R-roscovitine (to inhibit cdk2) and EGF receptor tyrosine kinase inhibitors. Inhibition of mTOR by rapamycin decreased cell proliferation and prevented cyst enlargement in several models including the Han:SPRD rat, orpk-rescue and $b p k$ mouse models [57]. Treatment with the cyclin-dependent kinase inhibitor R-roscovitine effectively arrested cystic disease in jck and $c p k$ mice [58]. Administration of EGF receptor tyrosine kinase inhibitors, EKB-569 and EKI785, markedly reduced cyst formation in $b p k$ mice and Han:SPRD rats, though not in the PCK rat. Alternative approaches to block downstream mitogenic signalling intermediates (e.g. ERK) have also been attempted [59].

In view of its stimulatory effects on cell proliferation and fluid secretion, a second major approach has been to target renal cAMP production. In landmark studies, administration of the vasopressin $\mathrm{V} 2$ receptor (V2R) antagonist, OPC31260, effectively inhibited disease development and progression in three rodent models - pcy mice, $\mathrm{PCK}$ rats and $\mathrm{Pkd} 2 \mathrm{WS}^{\mathrm{WS} /-}$ mice [60]. Vasopressin antagonism was associated with a decrease in kidney cAMP concentrations. Similarly, somatostatin treatment (which can inhibit cAMP-stimulated chloride secretion) led to a slowing in the rate of cyst volume expansion in a small study of ADPKD patients and in PCK rats [61]. The role of vasopressin action in modifying cyst expansion in ADPKD has been given added weight by recent studies which indirectly suppressed (high fluid intake) [62] or enhanced its action (endothelin B receptor blockade) [63] on the collecting duct.
Table 1 summarises other potential approaches that have been attempted in PKD models. Other features associated with cyst enlargement such as apoptosis, inflammation or interstitial fibrosis could represent alternative treatment targets. One note of caution is necessary when directly extrapolating results from cystic rodent models for human ADPKD. Clearly not all cystic diseases are the same. Apart from obvious differences in genotype, cysts may originate from different nephron segments and this could influence the effectiveness of different drugs [64]. We suggest that preclinical testing of candidate drugs should include the use of orthologous models of ADPKD as a minimum.

At present, blood pressure control remains the major treatment modality though currently, at least 3 major clinical trials seeking to alter the natural history of the disease (tolvaptan, rapamycin and somatostatin) are in progress. Given the complexity of the cystic disease process, it seems likely that a combination strategy will be required for maximal therapeutic benefit. The next decade holds much promise of an effective treatment for a once untreatable disease.

\section{Acknowledgements}

Work in the author's laboratory was supported by the Wellcome Trust, Polycystic Kidney Disease Foundation (USA), Research Councils UK, Kidney Research UK and the Medical Research Council. We apologise for omitting a more comprehensive bibliography due to space limitations.

\section{References}

-1 Hateboer N, v Dijk MA, Bogdanova N, Coto E, Saggar-Malik AK, San Millan JL, Torra R, Breuning M, Ravine D: Comparison of phenotypes of polycystic kidney disease types 1 and 2. European PKD1-PKD2 Study Group. Lancet 1999;353:103-107.

-2 Rossetti S, Burton S, Strmecki L, Pond GR, San Millan JL, Zerres K, Barratt TM, Ozen S, Torres VE, Bergstralh EJ, Winearls CG, Harris PC: The position of the polycystic kidney disease 1 (PKD1) gene mutation correlates with the severity of renal disease. J Am Soc Nephrol 2002;13:1230-1237.

-3 Rossetti S, Chauveau D, Kubly V, Slezak JM, Saggar-Malik AK, Pei Y, Ong AC, Stewart F, Watson ML, Bergstralh EJ, Winearls CG, Torres VE, Harris PC: Association of mutation position in polycystic kidney disease 1 (PKD1) gene and development of a vascular phenotype. Lancet 2003;361:2196-2201.
4 Magistroni R, He N, Wang K, Andrew R, Johnson A, Gabow P, Dicks E, Parfrey P, Torra R, San-Millan JL, Coto E, Van Dijk M, Breuning M, Peters D, Bogdanova N, Ligabue G, Albertazzi A, Hateboer N, Demetriou K, Pierides A, Deltas C, St George-Hyslop P, Ravine D, Pei Y: Genotype-renal function correlation in type 2 autosomal dominant polycystic kidney disease. J Am Soc Nephrol 2003; 14:1164-1174.

5 Persu A, Duyme M, Pirson Y, Lens XM, Messiaen T, Breuning $\mathrm{MH}$, Chauveau D, Levy M, Grunfeld JP, Devuyst O: Comparison between siblings and twins supports a role for modifier genes in ADPKD. Kidney Int 2004; $66: 2132-2136$
-6 Paterson AD, Magistroni R, He N, Wang K, Johnson A, Fain PR, Dicks E, Parfrey P, St George-Hyslop P, Pei Y: Progressive loss of renal function is an age-dependent heritable trait in type 1 autosomal dominant polycystic kidney disease. J Am Soc Nephrol 2005; 16:755-762.

7 Ong AC, Harris PC: Molecular pathogenesis of ADPKD: The polycystin complex gets complex. Kidney Int 2005;67:1234-1247.

8 Tazon-Vega B, Vilardell M, Perez-Oller L, Ars E, Ruiz P, Devuyst O, Lens X, FernandezLlama P, Ballarin J, Torra R: Study of candidate genes affecting the progression of renal disease in autosomal dominant polycystic kidney disease type 1 . Nephrol Dial Transplant 2007;22:1567-1577. 
>9 Qian F, Watnick TJ, Onuchic LF, Germino GG: The molecular basis of focal cyst formation in human autosomal dominant polycystic kidney disease type I. Cell 1996;87:979987.

10 Wu G, D’Agati V, Cai Y, Markowitz G, Park JH, Reynolds DM, Maeda Y, Le TC, Hou H Jr, Kucherlapati R, Edelmann W, Somlo S: Somatic inactivation of $\mathrm{Pkd} 2$ results in polycystic kidney disease. Cell 1998;93:177-188.

- 11 Lantinga-van Leeuwen IS, Dauwerse JG, Baelde HJ, Leonhard WN, van de Wal A, Ward CJ, Verbeek S, Deruiter MC, Breuning $\mathrm{MH}$, de Heer E, Peters DJ: Lowering of Pkd1 expression is sufficient to cause polycystic kidney disease. Hum Mol Genet 2004;13: 3069-3077.

-12 Jiang ST, Chiou YY, Wang E, Lin HK, Lin YT, Chi YC, Wang CK, Tang MJ, Li H: Defining a link with autosomal-dominant polycystic kidney disease in mice with congenitally low expression of Pkd1. Am J Pathol 2006;168: 205-220.

-13 Pritchard L, Sloane-Stanley JA, Sharpe JA, Aspinwall R, Lu W, Buckle V, Strmecki L, Walker D, Ward CJ, Alpers CE, Zhou J, Wood WG, Harris PC: A human PKD1 transgene generates functional polycystin-1 in mice and is associated with a cystic phenotype. Hum Mol Genet 2000;9:2617-2627.

14 Thivierge C, Kurbegovic A, Couillard M, Guillaume R, Cote O, Trudel M: Overexpression of PKD1 causes polycystic kidney disease. Mol Cell Biol 2006;26:1538-1548.

15 Ahrabi AK, Terryn S, Valenti G, Caron N, Serradeil-Le Gal C, Raufaste D, Nielsen S, Horie S, Verbavatz JM, Devuyst O: PKD1 Haploinsufficiency causes a syndrome of inappropriate antidiuresis in mice. J Am Soc Nephrol 2007; 18:1740-1753.

$\checkmark 16$ Chang MY, Parker E, Ibrahim S, Shortland JR, Nahas ME, Haylor JL, Ong AC: Haploinsufficiency of $\mathrm{Pkd} 2$ is associated with increased tubular cell proliferation and interstitial fibrosis in two murine Pkd2 models. Nephrol Dial Transplant 2006;21:20782084.

17 Qian Q, Hunter LW, Li M, Marin-Padilla M, Prakash YS, Somlo S, Harris PC, Torres VE, Sieck GC: Pkd2 haploinsufficiency alters intracellular calcium regulation in vascular smooth muscle cells. Hum Mol Genet 2003; 12:1875-1880.

- 18 Nauli SM, Rossetti S, Kolb RJ, Alenghat FJ, Consugar MB, Harris PC, Ingber DE, Loghman-Adham M, Zhou J: Loss of polycystin-1 in human cyst-lining epithelia leads to ciliary dysfunction. J Am Soc Nephrol 2006;17: 1015-1025

-19 Hughes J, Ward CJ, Peral B, Aspinwall R, Clark K, San Millan JL, Gamble V, Harris PC: The polycystic kidney disease 1 (PKD1) gene encodes a novel protein with multiple cell recognition domains. Nat Genet 1995; 10:151-160.
20 Newby LJ, Streets AJ, Zhao Y, Harris PC, Ward CJ, Ong AC: Identification, characterization, and localization of a novel kidney polycystin-1-polycystin-2 complex. J Biol Chem 2002;277:20763-20773.

21 Streets AJ, Newby LJ, O’Hare MJ, Bukanov NO, Ibraghimov-Beskrovnaya O, Ong AC: Functional analysis of PKD1 transgenic lines reveals a direct role for polycystin-1 in mediating cell-cell adhesion. J Am Soc Nephrol 2003;14:1804-1815.

22 Qian F, Wei W, Germino G, Oberhauser A: The nanomechanics of polycystin-1 extracellular region. J Biol Chem 2005;280:4072340730.

23 Chauvet V, Tian X, Husson H, Grimm DH, Wang T, Hieseberger T, Igarashi P, Bennett AM, Ibraghimov-Beskrovnaya O, Somlo S, Caplan MJ: Mechanical stimuli induce cleavage and nuclear translocation of the polycystin-1 C terminus. J Clin Invest 2004;114: 1433-1443.

24 Giamarchi A, Padilla F, Coste B, Raoux M, Crest M, Honore E, Delmas P: The versatile nature of the calcium-permeable cation channel TRPP2. EMBO Rep 2006;7:787793.

25 McGrath J, Somlo S, Makova S, Tian X, Brueckner M: Two populations of node monocilia initiate left-right asymmetry in the mouse. Cell 2003;114:61-73.

26 Nauli SM, Alenghat FJ, Luo Y, Williams E, Vassilev P, Li X, Elia AE, Lu W, Brown EM, Quinn SJ, Ingber DE, Zhou J: Polycystins 1 and 2 mediate mechanosensation in the primary cilium of kidney cells. Nat Genet 2003; 33:129-137.

27 Kottgen M, Benzing T, Simmen T, Tauber R, Buchholz B, Feliciangeli S, Huber TB, Schermer B, Kramer-Zucker A, Hopker K, Simmen KC, Tschucke CC, Sandford R, Kim E, Thomas G, Walz G: Trafficking of TRPP2 by PACS proteins represents a novel mechanism of ion channel regulation. EMBO J 2005;24:705-716.

28 Streets AJ, Moon DJ, Kane ME, Obara T, Ong AC: Identification of an N-terminal glycogen synthase kinase 3 phosphorylation site which regulates the functional localization of polycystin-2 in vivo and in vitro. Hum Mol Genet 2006;15:1465-1473.

29 Geng L, Okuhara D, Yu Z, Tian X, Cai Y, Shibazaki S, Somlo S: Polycystin-2 traffics to cilia independently of polycystin-1 by using an N-terminal RVxP motif. J Cell Sci 2006; 119:1383-1395.

30 Li Q, Montalbetti N, Wu Y, Ramos A, Raychowdhury MK, Chen XZ, Cantiello HF: Polycystin-2 cation channel function is under the control of microtubular structures in primary cilia of renal epithelial cells. J Biol Chem 2006;281:37566-37575.
31 Li Q, Montalbetti N, Shen PY, Dai XQ, Cheeseman CI, Karpinski E, Wu G, Cantiello HF, Chen XZ: Alpha-actinin associates with polycystin-2 and regulates its channel activity. Hum Mol Genet 2005;14:15871603.

32 Calvet JP: Molecular genetics of polycystic kidney disease. J Nephrol 1998;11:24-34.

33 Parker E, Newby LJ, Sharpe CC, Rossetti S, Streets AJ, Harris PC, O’Hare MJ, Ong AC: Hyperproliferation of PKD1 cystic cells is induced by insulin-like growth factor-1 activation of the Ras/Raf signalling system. Kidney Int 2007;72:157-165.

34 Yamaguchi T, Hempson SJ, Reif GA, Hedge AM, Wallace DP: Calcium restores a normal proliferation phenotype in human polycystic kidney disease epithelial cells. J Am Soc Nephrol 2006;17:178-187.

35 Leuenroth SJ, Okuhara D, Shotwell JD, Markowitz GS, Yu Z, Somlo S, Crews CM: Triptolide is a traditional Chinese medicine-derived inhibitor of polycystic kidney disease. Proc Natl Acad Sci USA 2007;104:43894394.

36 Veis DJ, Sorenson CM, Shutter JR, Korsmeyer SJ: Bcl-2-deficient mice demonstrate fulminant lymphoid apoptosis, polycystic kidneys, and hypopigmented hair. Cell 1993;75: 229-240.

37 Lanoix J, D’Agati V, Szabolcs M, Trudel M: Dysregulation of cellular proliferation and apoptosis mediates human autosomal dominant polycystic kidney disease (ADPKD). Oncogene 1996;13:1153-1160.

38 Trudel M, D’Agati V, Costantini F: C-myc as an inducer of polycystic kidney disease in transgenic mice. Kidney Int 1991;39:665671.

39 Boletta A, Qian F, Onuchic LF, Bhunia AK, Phakdeekitcharoen B, Hanaoka K, Guggino W, Monaco L, Germino GG: Polycystin-1, the gene product of PKD1, induces resistance to apoptosis and spontaneous tubulogenesis in MDCK cells. Mol Cell 2000;6:1267-1273.

40 Grantham JJ, Ye M, Gattone VH 2nd, Sullivan LP: In vitro fluid secretion by epithelium from polycystic kidneys. J Clin Invest 1995; 95:195-202.

41 Hanaoka K, Devuyst O, Schwiebert EM, Wilson PD, Guggino WB: A role for CFTR in human autosomal dominant polycystic kidney disease. Am J Physiol 1996;270:C389C399.

42 Wildman SS, Hooper KM, Turner CM, Sham JS, Lakatta EG, King BF, Unwin RJ, Sutters $\mathrm{M}$ : The isolated polycystin-1 cytoplasmic $\mathrm{COOH}$ terminus prolongs ATP-stimulated $\mathrm{Cl}^{-}$conductance through increased $\mathrm{Ca}^{2+}$ entry. Am J Physiol Renal Physiol 2003;285: F1168-F1178.

43 Mangoo-Karim R, Uchic M, Lechene C, Grantham JJ: Renal epithelial cyst formation and enlargement in vitro: dependence on cAMP. Proc Natl Acad Sci USA 1989;86: 6007-6011. 
-44 Schwiebert EM, Wallace DP, Braunstein GM, King SR, Peti-Peterdi J, Hanaoka K, Guggino WB, Guay-Woodford LM, Bell PD, Sullivan LP, Grantham JJ, Taylor AL: Autocrine extracellular purinergic signaling in epithelial cells derived from polycystic kidneys. Am J Physiol Renal Physiol 2002;282: F763-F775.

-45 Putnam WC, Swenson SM, Reif GA, Wallace DP, Helmkamp GM Jr, Grantham JJ: Identification of a forskolin-like molecule in human renal cysts. J Am Soc Nephrol 2007;18: 934-943.

46 Shannon MB, Patton BL, Harvey SJ, Miner $\mathrm{JH}$ : A hypomorphic mutation in the mouse laminin alpha5 gene causes polycystic kidney disease. J Am Soc Nephrol 2006;17:19131922.

-47 Wilson PD, Geng L, Li X, Burrow CR: The PKD1 gene product, 'polycystin-1,' is a tyrosine-phosphorylated protein that colocalizes with alpha2 beta1-integrin in focal clusters in adherent renal epithelia. Lab Invest 1999;79: 1311-1323.

-48 Battini L, Fedorova E, Macip S, Li X, Wilson PD, Gusella GL: Stable knockdown of polycystin-1 confers integrin-alpha2beta1-mediated anoikis resistance. J Am Soc Nephrol 2006;17:3049-3058.

-49 Charron AJ, Nakamura S, Bacallao R, Wandinger-Ness A: Compromised cytoarchitecture and polarized trafficking in autosomal dominant polycystic kidney disease cells. J Cell Biol 2000;149:111-124.

-50 Simons M, Gloy J, Ganner A, Bullerkotte A, Bashkurov M, Kronig C, Schermer B, Benzing T, Cabello OA, Jenny A, Mlodzik M, Polok B, Driever W, Obara T, Walz G: Inversin, the gene product mutated in nephronophthisis type II, functions as a molecular switch between Wnt signaling pathways. Nat Genet 2005;37:537-543.

-51 Fischer E, Legue E, Doyen A, Nato F, Nicolas JF, Torres V, Yaniv M, Pontoglio M: Defective planar cell polarity in polycystic kidney disease. Nat Genet 2006;38:21-23.

52 Ong AC, Wheatley DN: Polycystic kidney disease - the ciliary connection. Lancet 2003;361:774-776.
3 Barr MM, Sternberg PW: A polycystic kidney-disease gene homologue required for male mating behaviour in C. elegans. Nature 1999;401:386-389.

54 Pazour GJ, Dickert BL, Vucica Y, Seeley ES, Rosenbaum JL, Witman GB, Cole DG: Chlamydomonas IFT88 and its mouse homologue, polycystic kidney disease gene $\operatorname{tg} 737$, are required for assembly of cilia and flagella. J Cell Biol 2000;151:709-718.

55 Lin F, Hiesberger T, Cordes K, Sinclair AM, Goldstein LS, Somlo S, Igarashi P: Kidneyspecific inactivation of the KIF3A subunit of kinesin-II inhibits renal ciliogenesis and produces polycystic kidney disease. Proc Natl Acad Sci USA 2003;100:5286-5291.

56 Xu C, Rossetti S, Jiang L, Harris PC, BrownGlaberman U, Wandinger-Ness A, Bacallao R, Alper SL: Human ADPKD primary cyst epithelial cells with a novel, single codon deletion in the PKD1 gene exhibit defective ciliary polycystin localization and loss of flowinduced $\mathrm{Ca}^{2+}$ signaling. Am J Physiol Renal Physiol 2007;292:F930-F945.

57 Shillingford JM, Murcia NS, Larson CH, Low $\mathrm{SH}$, Hedgepeth R, Brown N, Flask CA, Novick AC, Goldfarb DA, Kramer-Zucker A, Walz G, Piontek KB, Germino GG, Weimbs $\mathrm{T}$ : The mTOR pathway is regulated by polycystin-1, and its inhibition reverses renal cystogenesis in polycystic kidney disease. Proc Natl Acad Sci USA 2006;103:54665471.

58 Bukanov NO, Smith LA, Klinger KW, Ledbetter SR, Ibraghimov-Beskrovnaya O: Long-lasting arrest of murine polycystic kidney disease with CDK inhibitor roscovitine. Nature 2006;444:949-952.

59 Omori S, Hida M, Fujita H, Takahashi H, Tanimura S, Kohno M, Awazu M: Extracellular signal-regulated kinase inhibition slows disease progression in mice with polycystic kidney disease. J Am Soc Nephrol 2006; 17:1604-1614.

60 Torres VE, Wang X, Qian Q, Somlo S, Harris PC, Gattone VH, 2nd: Effective treatment of an orthologous model of autosomal dominant polycystic kidney disease. Nat Med 2004; 10:363-364.
61 Ruggenenti P, Remuzzi A, Ondei P, Fasolini G, Antiga L, Ene-Iordache B, Remuzzi G, Epstein FH: Safety and efficacy of long-acting somatostatin treatment in autosomal-dominant polycystic kidney disease. Kidney Int 2005;68:206-216.

62 Nagao S, Nishii K, Katsuyama M, Kurahashi H, Marunouchi T, Takahashi H, Wallace DP: Increased water intake decreases progression of polycystic kidney disease in the PCK rat. J Am Soc Nephrol 2006;17:2220-2227.

63 Chang MY, Parker E, El Nahas M, Haylor JL, Ong AC: Endothelin B receptor blockade accelerates disease progression in a murine model of autosomal dominant polycystic kidney disease. J Am Soc Nephrol 2007;18: 560-569.

64 Guay-Woodford LM: Murine models of polycystic kidney disease: molecular and therapeutic insights. Am J Physiol Renal Physiol 2003;285:F1034-F1049.

65 Tao Y, Kim J, Schrier RW, Edelstein CL: Rapamycin markedly slows disease progression in a rat model of polycystic kidney disease. J Am Soc Nephrol 2005;16:46-51.

66 Sweeney WE, Chen Y, Nakanishi K, Frost P, Avner ED: Treatment of polycystic kidney disease with a novel tyrosine kinase inhibitor. Kidney Int 2000;57:33-40.

67 Torres VE, Sweeney WE, Jr., Wang X, Qian Q, Harris PC, Frost P, Avner ED: EGF receptor tyrosine kinase inhibition attenuates the development of PKD in Han:SPRD rats. Kidney Int 2003;64:1573-1579.

68 Obermuller N, Morente N, Kranzlin B, Gretz N, Witzgall R: A possible role for metalloproteinases in renal cyst development. Am J Physiol Renal Physiol 2001;280:F540-F550.

69 Tao Y, Kim J, Faubel S, Wu JC, Falk SA, Schrier RW, Edelstein CL: Caspase inhibition reduces tubular apoptosis and proliferation and slows disease progression in polycystic kidney disease. Proc Natl Acad Sci USA 2005;102:6954-6959.

70 Muto S, Aiba A, Saito Y, Nakao K, Nakamura K, Tomita K, Kitamura T, Kurabayashi M, Nagai R, Higashihara E, Harris PC, Katsuki M, Horie S: Pioglitazone improves the phenotype and molecular defects of a targeted Pkd1 mutant. Hum Mol Genet 2002;11:17311742. 